\title{
Dampak kepemimpinan transformasional dan pelatihan terhadap employee well-being: Keadilan organisasional sebagai mediator
}

\author{
Mei Ie* \\ Universitas Tarumanagara, Jl. Tanjung Duren Utara No. 1, Jakarta Barat, 11470, Indonesia \\ meii@fe.untar.ac.id \\ Henny Henny \\ Universitas Tarumanagara, Jl. Tanjung Duren Utara No. 1, Jakarta Barat, 11470, Indonesia \\ henny@fe.untar.ac.id \\ Atalya Fransiska \\ Universitas Tarumanagara, Jl. Tanjung Duren Utara No. 1, Jakarta Barat, 11470, Indonesia \\ atalya.115180014@stu.untar.ac.id \\ Viny Angellika \\ Universitas Tarumanagara, Jl. Tanjung Duren Utara No. 1, Jakarta Barat, 11470, Indonesia \\ viny.115180020@stu.untar.ac.id \\ Zefanya Salsabilla \\ Universitas Tarumanagara, Jl. Tanjung Duren Utara No. 1, Jakarta Barat, 11470, Indonesia \\ zefanya.115180032@stu.untar.ac.id \\ *Penulis Korespondensi
}

Submitted: Jun 14, 2021; Reviewed: Jun 24, 2021; Accepted: Nov 12, 2021

\begin{abstract}
The purpose of this study was to empirically examine the effect of transformational leadership and human resources training on employee well-being with organizational justice as a mediating variable. This study used purposive sampling. The sample consisted of 54 respondents who were employees, and the research data were analyzed using the SmartPLS version 3.3.2 software program. The results of this study indicated that transformational leadership and human resources training at the company have a significant and positive effect on employee well-being. This means that the better the transformational leadership is realized in the company, the higher the employee well-being in the company. However, based on the research results, organizational justice did not have a significant and negative effect on employee well-being. So that organizational justice cannot mediate the relationship between transformational leadership and human resources training for employee well-being. The implication of this research for companies in general is that companies can maintain and improve their employee well-being. Suggestions for the company, it is hoped that it can maintain and improve transformational leadership and conduct human resources training regularly and with good procedures to improve employee well-being in a company, because human capital is the one of the main capitals that it is important to be managed by the company.
\end{abstract}

Keywords: human resources training; organizational justice employee well-being; transformational leadership 
Abstrak: Tujuan penelitian ini adalah untuk menguji secara empiris pengaruh kepemimpinan transformasional dan pelatihan sumber daya manusia terhadap employee well-being dengan keadilan organisasional sebagai variabel mediasi. Penelitian ini menggunakan teknik purposive sampling. Sampel berjumlah 54 orang responden yang merupakan karyawan serta data penelitian ini dianalisis dengan menggunakan program software SmartPLS versi 3.3.2. Hasil penelitian ini menunjukkan bahwa kepemimpinan transformasional dan pelatihan sumber daya manusia pada perusahaan berpengaruh secara signifikan dan positif terhadap employee well-being. Artinya semakin baik kepemimpinan transformasional diwujudkan dalam perusahaan, maka semakin tinggi pula employee well-being pada perusahaan. Namun berdasarkan hasil penelitian, keadilan organisasional tidak berpengaruh secara signifikan dan negatif terhadap employee well-being, sehingga keadilan organisasional tidak dapat memediasi hubungan antara kepemimpinan transformasional dengan pelatihan sumber daya manusia terhadap employee well-being. Implikasi dari penelitian ini terhadap perusahaan secara umum adalah, agar perusahaan dapat mempertahankan dan meningkatkan employee well-beingnya. Saran bagi perusahaan, diharapkan dapat mempertahankan dan meningkatkan kepemimpinan transformasional serta melakukan pelatihan sumber daya manusia secara berkala dan dengan prosedur yang baik guna meningkatkan employee well-being dalam suatu perusahaan, karena tenaga kerja atau sumber saya manusia (human capital) adalah salah satu modal utama yang penting untuk dikelola oleh perusahaan.

Kata kunci: employee well-being; keadilan organisasional; kepemimpinan transformasional; pelatihan sumber daya manusia

\section{PENDAHULUAN}

Perusahaan dan karyawan merupakan dua pihak yang saling terkait dan membutuhkan. Perusahaan tanpa adanya karyawan, maka operasional perusahaan tidak dapat berjalan dengan baik. Karyawan juga membutuhkan perusahaan sebagai sumber penghasilannya dan tempat mengaktualisasikan kemampuan serta keterampilan yang dimilikinya.

Perlu diperhatikan oleh perusahaan, bahwa employee well-being juga merupakan bentuk pelayanan dari perusahaan kepada para pekerjanya di luar dari gaji dan insentif yang didapatkannya. Inceoglu et. al. (2018) menyatakan bahwa employee well-being merupakan hal yang penting untuk kelangsungan hidup dan perkembangan perusahaan. Sedangkan Jaiswal \& Dyaram (2019) menyatakan bahwa employee well-being merupakan bagian penting dari kepuasan hidup karyawan secara keseluruhan. Dengan pernyataan-pernyataan yang sudah dijabarkan, dapat disimpulkan bahwa employee well-being merupakan suatu hal yang krusial dan harus diwujudkan oleh setiap perusahaan, sehingga perusahaan yang sudah mengetahui tentang betapa berpengaruhnya employee well-being, seharusnya dapat lebih memperhatikan employee well-being para pekerjanya dan tidak hanya memprioritaskan profit perusahaan. Pernyataan ini juga didukung oleh Khoreva \& Wechsler (2018) yang berhasil membuktikan bahwa pekerja yang memiliki tingkat employee well-being yang tinggi cenderung lebih kreatif dan berkinerja baik di tempat kerja daripada para pekerja yang memiliki tingkat employee well-being yang rendah.

Dalam kondisi saat ini, perubahan lingkungan yang terjadi cukup memberikan pengaruh pada banyak perusahaan, khususnya pada karyawan. Kenyataannya, perusahaan yang baik bukan hanya perusahaan yang dapat meraih profit yang tinggi, tetapi juga mempertahankan kepemimpinan yang baik, yang nantinya akan berdampak pada employee well-being di perusahaan. Menurut Jufrizen \& Lubis (2020), salah satu variabel yang memengaruhi karyawan adalah kepemimpinan transformasional. Afsar \& Umrani (2019) menggambarkan kepemimpinan transformasional sebagai proses di mana seorang pemimpin memainkan model peran yang diidealkan yang bertujuan untuk merangsang perilaku kreatif karyawan, mendukung dan membimbing karyawan, serta memberikan motivasi inspiratif kepada karyawan untuk mencapai visi dan tujuan bersama. Hal inilah yang harus diperhatikan oleh para pemimpin dalam mengarahkan karyawannya. Tidak hanya itu saja, Khaola \& Rambe (2020) juga menyatakan bahwa kepemimpinan dapat memengaruhi persepsi karyawan tentang keadilan organisasional. Pernyataan ini juga diperkuat oleh Nielsen \& Marrone (2018) yang menyatakan bahwa baik dalam kapasitas individu maupun sebagai agen organisasi, pemimpin merupakan sumber keadilan dalam organisasi. Pernyataan-pernyataan ini seharusnya sudah bisa membuktikan bahwa kepemimpinan bukanlah hal yang mudah untuk dilakukan, tetapi jika dilakukan haruslah dengan pemikiran yang 
matang. Karena kunci utama suatu perusahaan dikatakan sukses adalah bukan dengan memaksakan kehendak untuk mencapai tujuan perusahaan. Mencapai tujuan perusahaan adalah keharusan, tetapi employee well-being merupakan kewajiban perusahaan.

Di samping kepemimpinan, pelatihan sumber daya manusia juga ikut memengaruhi employee wellbeing pada suatu perusahaan. Casademunt et al. (2018) menyatakan bahwa pelatihan SDM yang tepat adalah yang sesuai dengan beberapa karakteristik organisasi yang relevan. Zhang et al. (2020) menyatakan bahwa pelatihan-pelatihan yang efektif akan berdampak secara langsung terhadap employee well-being. Karyawan yang menguasai pekerjaannya, akan merasa tidak terbebani oleh setiap pekerjaan yang diberikan oleh perusahaan. Hal ini dapat terjadi karena tidak ada rasa kekhawatiran dalam diri karyawan terkait pekerjaannya, sehingga akhirnya karyawan dapat bekerja dengan perasaan yang nyaman tanpa perlu merasa gelisah setiap harus datang ke kantor. Pelatihan SDM merupakan pelatihan yang bertujuan untuk membangun kinerja karyawan dengan menambah wawasan, pengalaman, serta skill karyawan. Dalam praktik nyatanya, pelatihan SDM di berbagai perusahaan belum sepenuhnya berjalan dengan baik dan benar. Padahal, pelatihan SDM dapat menjadi salah satu acuan untuk menilai bahwa suatu perusahaan sudah berhasil mengelola SDM nya dengan baik dan benar. Perusahaan tidak dapat melupakan bahwa SDM dalam perusahaan juga merupakan human capital yang harus dijaga dan dipertahankan. Selain itu, pelatihan SDM juga dapat digunakan sebagai patokan untuk menilai suatu perusahaan sudah melakukan keadilan organisasional di dalamnya atau belum. Pernyataan ini juga sesuai dengan Zhang et al. (2020) yang menyatakan bahwa keadilan organisasional mempunyai peran dalam memediasi dampak dari pelatihan SDM terhadap employee well-being.

Penelitian ini bertujuan untuk menguji secara empiris pengaruh kepemimpinan transformasional dan pelatihan SDM terhadap employee well-being dengan keadilan organisasional sebagai mediator. Hasil penelitian ini diharapkan dapat memberikan kontribusi untuk mendapatkan gambaran tentang pentingnya employee well-being dalam suatu perusahaan.

Beberapa peneliti terdahulu berpendapat dan dapat membuktikan bahwa employee well-being dapat diberikan dalam bentuk non-materi, seperti yang dinyatakan oleh Sharma et al. (2016) bahwa employee well-being merupakan konstruksi holistik yang tidak hanya terdiri dari unsur fisik dan mental tetapi juga mencakup aspek spiritual dan emosional. Amanda \& Sadida (2018) juga menyatakan bahwa, employee well-being merupakan aspek penting untuk menunjang produktivitas sumber daya manusia dalam suatu perusahaan. Sedangkan Otalora et al. (2020) mendefinisikan employee well-being sebagai hasil evaluasi sejauh mana pekerjaan dapat memberi karyawan perasaaan senang. Namun uniknya, terdapat hasil uji beda antara employee well-being dengan status perkawinan yang dipaparkan oleh Rizky \& Sadida (2019). Mereka menyatakan bahwa karyawan yang menikah memiliki employee well-being yang lebih bagus dibandingkan karyawan yang belum menikah. Hal ini juga nantinya harus menjadi bahan pertimbangan perusahaan untuk lebih memerhatikan karyawan beserta dengan keluarganya. Dari penjabaran beberapa definisi di atas, dapat disimpulkan bahwa employee well-being merupakan hal yang krusial bukan hanya bagi pihak pekerja saja, tetapi juga bagi pihak perusahaan. Berdasarkan Zheng et al. (2015), employee well-being mempunyai beberapa dimensi, yaitu: life well-being, job well-being, dan psychological well-being. Life well-being karyawan meliputi seluruh aspek dalam hidupnya termasuk di dalamnya keluarga serta kesehatan fisik, sedangkan job well-being meliputi kesejahteraan pekerjaan yang dapat dirasakan dari perusahaannya, dan terakhir psychological well-being meliputi kesejahteraan untuk kesehatan mental karyawan. Sehingga dimensi inilah yang akan digunakan dalam penelitian untuk membantu peneliti.

Kepemimpinan transformasional merupakan gaya kepemimpinan yang mampu membuat para karyawan bekerja tanpa rasa terpaksa dan membiarkan karyawan untuk terus berkembang di dalam organisasi serta mempunyai hubungan yang dekat dengan pemimpinnya. Pernyataan ini didukung juga oleh Septyan et al. (2017) yang menyatakan kepemimpinan transformasional meliputi hubungan yang lebih intens antara pemimpin dan karyawannya. Hubungan yang lebih intens dengan karyawan dapat memengaruhi karyawan agar mau menjalankan perintah dengan senang hati tanpa paksaan. Jufrizen \& Lubis (2020) mendefinisikan kepemimpinan transformasional sebagai tipe kepemimpinan yang memimpin dan memotivasi karyawan mereka dalam arah tujuan yang ditegakkan dengan memperjelas peran dan tuntutan tugas. Sedangkan kepemimpinan transformasional didefinisikan oleh Fernandes \& Fresly (2017) sebagai contoh moral bekerja untuk menuju manfaat sebuah tim. Pemimpin transformasional biasanya akan mempertimbangan dan peduli dengan kekhawatiran dan pertimbangan para pekerjanya. Samad et al. (2021) menjelaskan kepemimpinan transformasional memiliki empat 
dimensi, yaitu: (1) pertimbangan individual, (2) stimulasi intelektual, (3) motivasi inspirasional, dan (4) pengaruh ideal. Oleh karena itu, seluruh dimensi ini perlu diperhatikan dengan cermat dan diimplementasikan dengan baik. Selain itu, dimensi inilah yang akan digunakan dalam penelitian untuk membantu peneliti.

Menurut Khoreva \& Wechtler (2018), pelatihan SDM yang meningkatkan keterampilan dapat membantu karyawan untuk menguasai kemampuan terkait pekerjaannya. Selain itu, Zhang et al. (2020) dapat membuktikan bahwa pelatihan SDM juga dapat digunakan sebagai alat untuk meningkatkan motivasi intrinsik maupun ekstrinsik karyawan untuk bekerja dengan memberikan kinerja yang diharapkan. Gope et al. (2018) mendefinisikan pelatihan SDM sebagai suatu bentuk upaya perusahaan untuk mengelola sumber daya manusianya sendiri dengan memfasilitasi pengembangan kompetensi yang spesifik, sehingga menghasilkan hubungan sosial yang kompleks serta pengetahuan terkait perusahaan untuk mempertahankan keunggulan. Dari beberapa penjabaran di atas, dapat disimpulkan bahwa pelatihan SDM merupakan rangkaian aktivitas yang bertujuan untuk meningkatkan nilai SDM serta keterampilan yang dimilikinya. Terdapat beberapa faktor yang memengaruhi pelatihan SDM menurut Zhang et al. (2020), yaitu kemampuan, motivasi, dan keberuntungan. Seluruh dimensi pelatihan SDM mempunyai keterkaitan satu dengan yang lainnya, namun yang paling utama adalah perusahaan harus berusaha untuk memotivasi karyawannya melalui pelatihan SDM yang disediakan.

Kim et al. (2017) mendefinisikan keadilan organisasional sebagai persepsi karyawan yang merasa diperlakukan secara adil dalam bekerja, bahwa semakin tinggi kemampuan perusahaan untuk memberikan keadilan bagi para karyawannya maka semakin terikat juga karyawannya dalam perusahaan. Namun jika keadilan tidak dirasakan oleh karyawan, maka keinginan karyawan untuk pindah kerja juga akan meningkat. Pernyataan sebelumnya juga didukung oleh pernyataan dari Hidayat (2015) yang mengungkapkan bahwa keadilan organisasional pada hakikatnya adalah persepsi individu terhadap keadilan perlakuan yang mereka terima di tempat kerja dan perlakuan tersebut nantinya akan berpengaruh pada sikap serta perilaku karyawan yang selanjutnya akan berdampak pada keberhasilan dalam suatu organisasi. Sedangkan definisi lain dari keadilan organisasional dijelaskan oleh Terzi et al. (2017) yang menyatakan bahwa keadilan organisasional adalah prediktor identifikasi dalam suatu organisasi, karena semakin tinggi persepsi keadilan, semakin tinggi pula tingkat identifikasinya. Keadilan organisasional sendiri mencerminkan sejauh mana karyawan dapat dilayani secara adil oleh perusahaan. Keadilan organisasional akan didapatkan ketika membandingkan antara usaha dan hasil yang diberikan kepada seorang karyawan, sama dengan karyawan lainnya. Menurut Josef (2017), keadilan organisasional mempunyai tiga dimensi, yaitu: adalah keadilan prosedural, keadilan distributif, dan keadilan interaksional. Keadilan prosedural lebih melibatkan imbalan dalam prosesnya, keadilan distributif ditandai dengan pendistribusian sumber daya dan keputusan secara adil, serta keadilan interaksional didefinisikan keadilan hubungan antara pribadi organisasi dan aksesibilitas terhadap peluang yang sama. Sehingga, dimensi inilah yang akan digunakan dalam penelitian untuk membantu peneliti.

Salah satu penelitian kepemimpinan dari Arnold (2017) menyatakan bahwa kepemimpinan transformasional akan berdampak positif terhadap employee well-being. Selain itu, Zhong et al. (2019) juga merupakan salah satu peneliti yang sudah meneliti gaya kepemimpinan yang berdampak pada employee well-being dan gaya kepemimpinan yang diteliti adalah kepemimpinan transformasional dan hasilnya bersifat positif. Hal ini dapat menandakan bahwa jika suatu kepemimpinan transformasional di dalam suatu perusahaan tinggi, maka kesejahteraan karyawan diperusahaan tersebut juga tinggi.

Mengacu Zhang et al. (2020), pelatihan SDM merupakan suatu acuan karyawan untuk dapat menilai jika perusahaan atau organisasi tempatnya bekerja mendukung dan peduli dengan mereka, serta seberapa besar nilai tersebut. Perusahaan yang menghargai dan memikirkan kesejahteraan karyawannya dalam bentuk memberikan dukungan dan kepedulian dapat diwujudkan melalui pelatihan SDM.

Le et al. (2016) berpendapat bahwa keadilan organisasional mempunyai peran yang bersifat krusial terhadap employee well-being yang dimensi utama di dalamnya adalah employee health (kesehatan karyawan). Akibat yang dipaparkan oleh Le et al. (2016) adalah ketidakadilan atau lack of justice dapat menyebabkan gangguan dan akhirnya penurunan terhadap employee health dan employee well-being. Sehingga keadilan organisasional mempunyai andil yang cukup dalam employee well-being dalam suatu perusahaan.

Dalam penelitiannya, Khaola \& Rambe (2020) menyatakan bahwa kepemimpinan dapat memengaruhi persepsi karyawan tentang keadilan organisasional. Artinya adalah kepemimpinan akan 
bertanggung jawab untuk menciptakan keadilan dan ketidakadilan yang muncul dari persepsi karyawan. Sedangkan Septyarini \& Pratiwi (2020) membuktikan bahwa adanya pengaruh positif dan signifikan antara keadilan organisasional terhadap employee well-being, juga adanya pengaruh positif dan signifikan antara keadilan organisasional dan kepemimpinan.

Zhang et al. (2020) menjelaskan bahwa ketika karyawan mengalami rasa keadilan organisasional yang tinggi, mereka akan merasakan dukungan dan pengakuan yang lebih besar dari para pemimpin mereka. Yang artinya adalah, dengan adanya pelatihan SDM, memungkinkan karyawan untuk menyadari pentingnya peran mereka dalam suatu perusahaan, dan akan berdampak positif terhadap sikap dan emosi (kesehatan mental) karyawan. Akhirnya, employee well-being dalam suatu organisasi atau perusahaan akan meningkat. Casademunt et al. (2018) menyatakan bahwa pelatihan SDM mempunyai keterikatan dengan employee well-being dalam suatu perusahaan. Pelatihan SDM juga dapat digunakan sebagai alat ukur untuk mengukur berbagai praktik sumber daya manusia dalam perusahaan, sudah atau belumnya dijalankan secara merata dan adil.

Adapun model penelitian ini dapat digambarkan sebagai berikut:

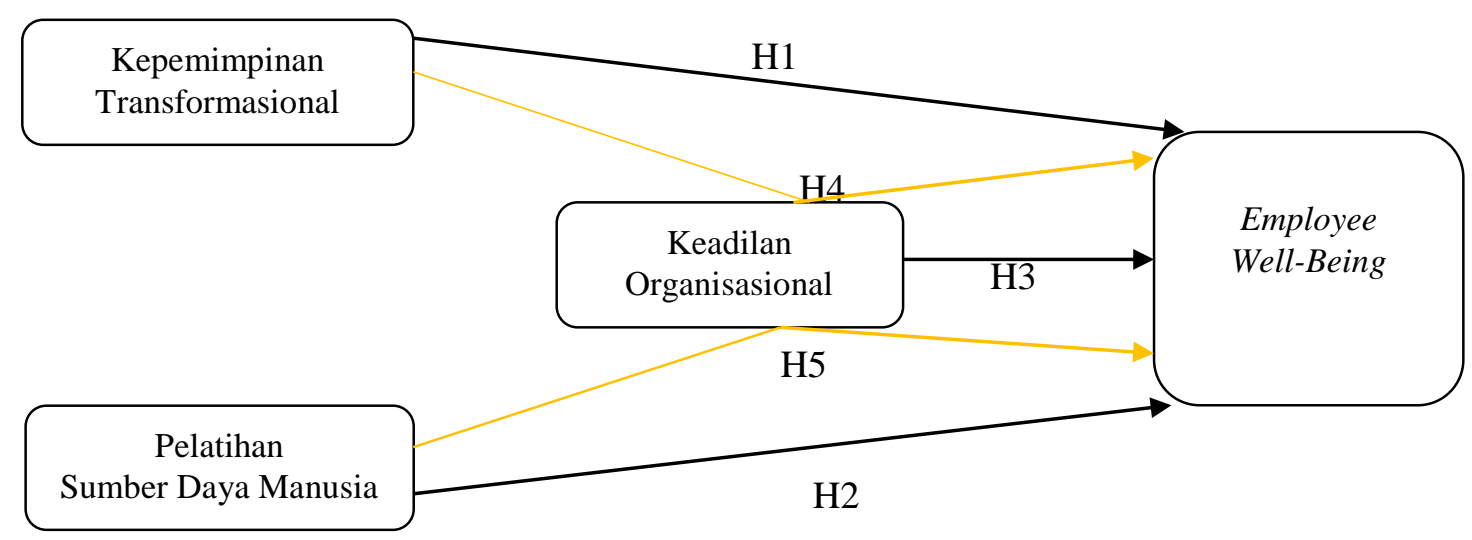

Gambar 1. Model penelitian

Sumber: Hasil pengolahan data (2021)

Berdasarkan definisi variabel dan kerangka pemikiran yang dibahas, dapat ditetapkan hipotesis penelitian sebagai berikut:

H1: Terdapat pengaruh positif kepemimpinan transformasional terhadap employee well- being.

$\mathrm{H} 2$ : Terdapat pengaruh positif pelatihan sumber daya manusia terhadap employee well-being.

H3: Terdapat pengaruh positif keadilan organisasional terhadap employee well-being.

H4: Keadilan organisasional dapat memediasi pengaruh positif kepemimpinan transformasional terhadap employee well-being.

H5: Keadilan organisasional dapat memediasi pengaruh positif pelatihan sumber daya manusia terhadap employee well-being.

\section{METODE}

Populasi penelitian ini adalah para karyawan yang bekerja pada perusahaan yang bergerak pada industri fasilitatif. Alasan peneliti untuk melakukan penelitian terhadap perusahaan ini karena tertarik tentang bagaimana perusahaan besar dan yang sudah diakui oleh masyarakat ini mengelola karyawan dengan baik sehingga karyawannya juga dikenal karena keramahan dan profesionalitasnya, sehingga menimbulkan pertanyaan seperti apakah employee well-being di perusahaan ini tercipta dengan sangat baik sehingga menghasilkan karyawan yang baik juga.

Penelitian ini dilakukan pada salah satu kantor cabang PT XYZ, dengan populasi sebanyak 60 orang. Sampel penelitian ini dipilih dengan metode non-probability sampling, teknik purposive sampling. Sampel penelitian merupakan karyawan di salah satu cabang PT. XYZ di Jakarta, sebanyak 54 orang. Kriteria pemilihan sampel adalah lokasi cabang perusahaan dan juga masa kerja karyawan minimal satu tahun. 
Kuesioner dari penelitian ini merupakan kuesioner tertutup dan disebarkan secara online menggunakan google form. Variabel employee well-being dianalisis dari indikator: (1) life well-being, (2) job well-being, dan (3) psychological well. Variabel kepemimpinan transformasional dianalisis dari indikator, yaitu: (1) pertimbangan individual, (2) stimulasi intelektual, (3) motivasi inspirasional, dan (4) pengaruh ideal. Pelatihan sumber daya manusia dianalisis dari indikator: (1) kemampuan, (2) motivasi, dan (3) keberuntungan. Varibel keadilan organisasional dianalisis dari indikator: (1) keadilan prosedural, (2) keadilan distributif, dan (3) keadilan interaksional.

Indikator-indikator dari variabel yang dibahas dalam penelitian ini diukur dengan menggunakan skala Likert, dari 1 sampai 5 dengan keterangan sebagai berikut: (1) sangat tidak setuju; (2) tidak setuju; (3) cukup setuju; (4) setuju; dan (5) sangat setuju. Hasil data dari kuesioner menunjukkan bahwa mayoritas responden adalah wanita $(61,8 \%)$ dengan rentang umur antara $18-25$ tahun $(58,2 \%)$ dan pendidikan terakhir adalah sarjana (50,9\%), serta lama bekerja 1-5 tahun $(56,4 \%)$. Data penelitian ini dianalisis dengan menggunakan program software SmartPLS versi 3.3.2.

\section{HASIL DAN PEMBAHASAN}

Berdasarkan pendapat dari Hair et al. (2014), analisis validitas konvergen dilihat dari nilai outer loadings $>0.7$ dan nilai average variance extracted $(A V E) \geq 0.5$, sedangkan analisis validitas diskriminan dilihat dari nilai composite reliability, yaitu > 0.6. Untuk ketentuan Cronbach's Alpha menurut Kuncoro (2013), adalah lebih besar dari 0.6.

Langkah pertama dilakukan adalah memilih outer loadings yang bernilai di atas 0.7 di setiap indikator pada setiap variabel, sehingga menghasilkan framework pada Gambar 2. Seluruh indikator yang terlampir dinilai sudah valid secara konvergen karena memiliki outer loadings lebih besar dari 0.7 serta nilai average variance extracted (AVE) pada setiap variabel lebih besar sama dengan dari 0.5 . Pada nilai outer loadings di cross loadings, seluruh indikator pada masing-masing variabel memiliki nilai lebih dari 0.7 , dengan demikian dapat dinyatakan bahwa telah memenuhi syarat dan valid serta dapat digunakan untuk analisis data lebih lanjut.

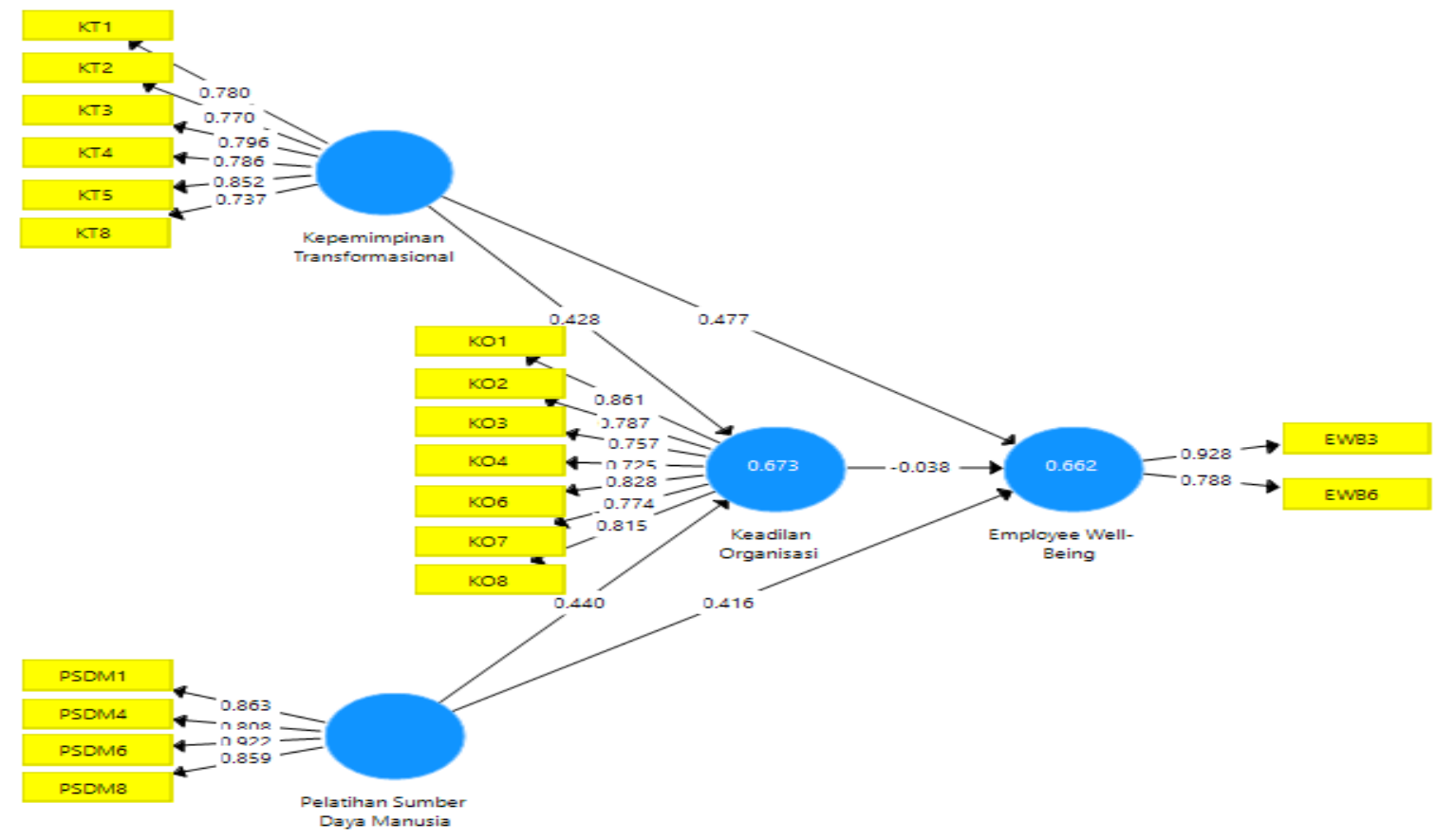

Gambar 2. Output smartPLS nilai outer loadings dan AVE

Sumber: Hasil pengolahan smartPLS (2021) 
Jurnal Manajemen Maranatha • Vol. 21 Nomor 1, November (2021)

Tabel 1. Hasil uji reliabilitas

\begin{tabular}{lcccc}
\hline \multicolumn{1}{c}{ Variabel } & $\begin{array}{c}\text { Composite } \\
\text { Reliability }\end{array}$ & $\begin{array}{c}\text { Cronbachs's } \\
\text { Alpha }\end{array}$ & AVE & Keterangan \\
\hline Kepemimpinan transformasional & 0.851 & 0.670 & 0.620 & Reliabel \\
\hline Pelatihan sumber daya manusia & 0.922 & 0.902 & 0.746 & Reliabel \\
\hline Keadilan organisasional & 0.907 & 0.877 & 0.630 & Reliabel \\
\hline Employee well-being & 0.921 & 0.887 & 0.742 & Reliabel \\
\hline
\end{tabular}

Sumber: Hasil pengolahan data smartPLS (2021)

Dari hasil pengujian di atas, dapat diketahui bahwa semua variabel dapat dinyatakan reliabel karena memiliki nilai composire reliability dan cronbach's alpha yang lebih besar dari 0.6. Artinya adalah, semua indikator pada variabel dapat mengukur variabel kepemimpinan transformasional, pelatihan sumber daya manusia, keadilan organisasional, dan employee well-being. Sedangkan nilai $R$-square $\left(\mathrm{R}^{2}\right)$ yang dihasilkan pada employee well-being adalah $66.2 \%$, yang artinya variabel employee well-being dipengaruhi oleh variabel kepemimpinan transformasional, pelatihan sumber daya manusia, dan keadilan organisasi sebesar 66.2\%. Dan hasil $\mathrm{R}^{2}$ dari keadilan organisasional adalah $67.3 \%$, yang artinya variabel keadilan organisasional dipengaruhi oleh kepemimpinan transformasional dan pelatihan sumber daya manusia sebesar $67.3 \%$.

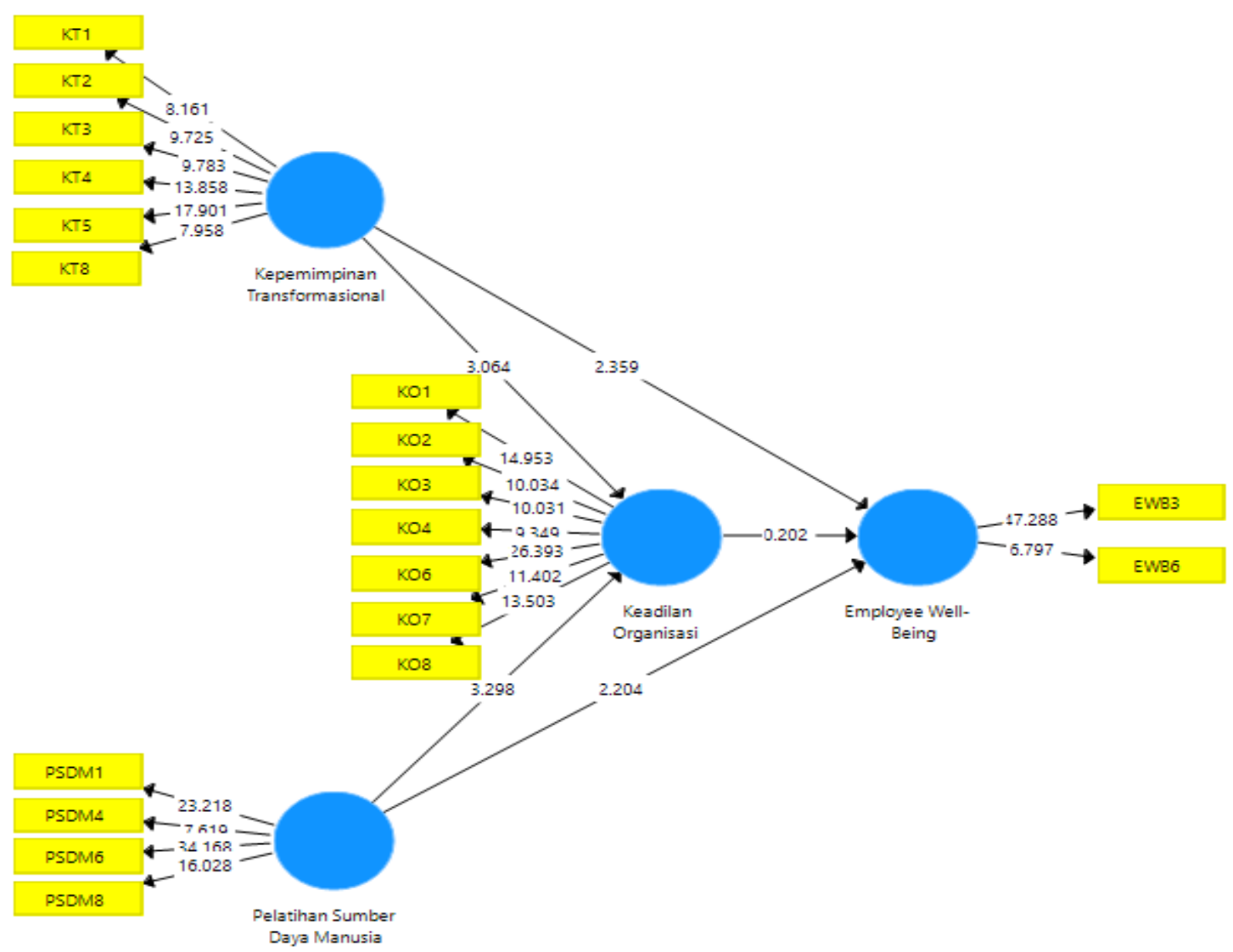

Gambar 3. Output smartPLS hasil bootstrapping

Sumber: Hasil pengolahan smartPLS (2021)

Tabel 2. Hasil pengujian hipotesis

\begin{tabular}{lccccc}
\hline & $\begin{array}{c}\text { Original } \\
\text { Sample }(\mathrm{O})\end{array}$ & $\begin{array}{c}\text { Sample } \\
\text { Mean }(\mathrm{M})\end{array}$ & $\begin{array}{c}\text { Standard } \\
\text { Deviation } \\
(\mathrm{STDEV})\end{array}$ & $\begin{array}{c}\text { T Statistics } \\
(\mid \mathrm{O} / \mathrm{STDEV})\end{array}$ & P Values \\
\hline $\begin{array}{l}\text { Keadilan organisasional } \\
\text { Employee well-being }\end{array}$ & -0.038 & -0.044 & 0.187 & 0.204 & 0.839 \\
\hline
\end{tabular}




\begin{tabular}{|c|c|c|c|c|c|}
\hline $\begin{array}{l}\text { Kepemimpinan } \\
\text { transformasional } \\
\text { Employee well-being }\end{array}$ & 0.477 & 0.455 & 0.193 & 2.475 & 0.014 \\
\hline $\begin{array}{l}\text { Kepemimpinan } \\
\text { transformasional } \\
\text { Keadilan organisasional }\end{array}$ & 0.428 & 0.408 & 0.138 & 3.106 & 0.002 \\
\hline $\begin{array}{l}\text { Pelatihan sumber daya } \\
\text { manusia } \rightarrow> \\
\text { being }\end{array}$ & 0.416 & 0.453 & 0.198 & 2.103 & 0.036 \\
\hline $\begin{array}{llr}\text { Pelatihan } & \text { sumber } & \text { daya } \\
\text { manusia } & -> & \text { Keadilan } \\
\text { organisasional } & \end{array}$ & 0.440 & 0.464 & 0.135 & 3.253 & 0.001 \\
\hline
\end{tabular}

Sumber: Hasil pengolahan data smartPLS (2021)

Dilihat dari hasil uji hipotesis pertama (H1), kepemimpinan transformasional dan employee wellbeing berpengaruh secara signifikan (t-statistic $2.475>1.96$ dan $\mathrm{p}$-value $0.014<0.05$ ) dan bersifat positif ( $\beta$ bernilai 0.477). Sesuai dengan pernyataan dari Samad et al. (2021) yang saat itu meneliti akademisi dan para staf profesional dari universitas regional Australia, membuktikan bahwa semakin karyawan mempresepsikan pemimpinnya sebagai pemimpin transformasional, semakin karyawan mempersepsikan peningkatan employee well-being dalam suatu perusahaan. Dari hasil uji hipotesis kedua $(\mathrm{H} 2)$, pelatihan sumber daya manusia berpengaruh signifikan terhadap employee well-being (tstatistic 2,103> 1.96 dan p-value $0.036<0.05)$ dan bersifat positif $(\beta$ bernilai 0.416$)$. Sesuai dengan pernyataan dari Khoreva \& Wechtler (2018) yang membuktikan dalam penelitiannya bahwa dimensidimensi dalam pelatihan sumber daya manusia dapat menyebabkan kenaikan pada employee well-being, terutama dalam psychological employee well-being. Selain itu, Zhang et al. (2020) juga menambahkan bahwa ketiga dimensi pelatihan sumber daya manusia (motivasi, keberuntungan, dan kemampuan) mempunyai dampak yang positif terhadap employee well-being dalam suatu perusahaan. Dari hasil uji hipotesis ketiga (H3), keadilan organisasional tidak berpengaruh signifkan terhadap employee wellbeing ( $\mathrm{t}$-statistic $0.204<1.96$ dan $\mathrm{p}$-value $0.839>0.05)$. Hasil penelitian ini berbeda dengan hasil yang disampaikan oleh Le et al. (2016) bahwa keadilan organisasional yang dirasakan secara positif oleh para karyawan akan terkait dengan employee well-being. Demikian juga dengan Septyrini \& Pratiwi (2020) yang menyatakan bahwa keadilan organisasional yang baik akan meningkatkan employee well-being, terutama pada psychological employee well-being.

Tabel 3. Hasil pengujian hipotesis mediasi

\begin{tabular}{ccccc} 
Original & Sample & Standard & T Statistics & \\
Sample $(\mathrm{O})$ & Mean $(\mathrm{M})$ & $\begin{array}{c}\text { Deviation } \\
(\mathrm{STDEV})\end{array}$ & $\begin{array}{c}\text { P Values } \\
(|\mathrm{O} / \mathrm{STDEV}|)\end{array}$ & \\
\hline
\end{tabular}

Kepemimpinan

transformasional $\rightarrow$

Keadilan organisasional $\rightarrow \quad-0.016 \quad-0.015 \quad 0.08$

0.203

0.839

Employee well-being

Pelatihan sumber daya

manusia $\rightarrow$ Keadilan

organisasional $\rightarrow$ Employee

$\begin{array}{llll}-0.017 & -0.024 & 0.094 & 0.178\end{array}$

0.859

well-being

Sumber: Hasil pengolahan data smartPLS (2021)

Berdasarkan hasil didapat dari data specific indirect effect, dapat diketahui pengaruh mediasi dengan variabel lainnya. Hasil uji hipotesis keempat $(\mathrm{H} 4)$, keadilan organisasional tidak dapat memediasi (no mediation) pengaruh kepemimpinan transformasional terhadap employee well-being. Dilihat dari nilai t-statistic $0.203<1.96$ dan $\beta$ sebesar -0.016 serta $\mathrm{p}$-value $0.839>0.05$, mengartikan bahwa keadilan organisasional tidak dapat memediasi hubungan antara kepemimpinan transformasional dan employee well-being. Hasil penelitian ini tidak sejalan dengan penelitian Septyrini \& Pratiwi (2020). Dalam 
penelitian ini, hubungan antara kepemimpinan transformasional dan employee well-being tidak dapat dimediasi dengan keadilan organisasional. Hal tersebut sejalan dengan pendapat Armold (2017) yang menyatakan bahwa pengaruh kepemimpinan transformasional dan employee well-being lebih berpengaruh secara langsung.

Sedangkan untuk hasil uji hipotesis kelima (H5), keadilan organisasional tidak dapat memediasi (no mediation) pengaruh pelatihan sumber daya manusia dengan employee well-being. Dilihat dari nilai tstatistic $0.178<1.96$ dan $\beta$ sebesar -0.017 serta p-value $0.859>0.05$, mengartikan bahwa keadilan organisasional tidak dapat memediasi hubungan antara pelatihan sumber daya manusia dan employee well-being. Hasil penelitian ini tidak sejalan dengan penelitian Zhang et al. (2020). Hasil penelitian ini menyatakan bahwa pengaruh pelatihan sumber daya manusia dengan employee well-being tidak dapat dimediasi oleh keadilan organisasional.

\section{SIMPULAN DAN SARAN}

Berdasarkan hasil penelitian, kepemimpinan transformasional berpengaruh secara signifikan dan positif terhadap employee well-being, yang artinya semakin baik dan semakin tinggi kepemimpinan transformasional dalam suatu perusahaan, maka employee well-being dalam suatu perusahaan juga akan dapat tercapai dengan baik dan tinggi. Begitu juga dengan pelatihan sumber daya manusia yang berpengaruh secara signifikan dan positif terhadap employee well-being, yang artinya semakin berkualitas (menggunakan metode yang baik, membangkitkan motivasi karyawan, dapat mengembangkan kemampuan karyawannya) pelatihan sumber daya manusia dijalankan dalam suatu perusahaan, maka akan semakin mudah juga employee well-being tercapai dalam perusahaan yang bersangkutan. Sedangkan, hasil penelitian mengenai pengaruh keadilan organisasional terhadap employee well-being ternyata tidak signifikan. Salah satu faktor yang paling mendasari rendahnya keadilan organisasional pada perusahaan ini adalah hasil kuesioner yang menyatakan masih ada karyawan yang merasa bahwa pendapatnya tidak didengarkan oleh pimpinan perusahaan dalam pengambilan keputusan serta ada yang merasa belum menerima perlakuan yang sama antar karyawan, sehingga menimbulkan persepsi adanya perbedaan dalam memperlakukan karyawan satu dengan yang lainnya. Hasil inilah yang kemudian berdampak pada hubungan antara kepemimpinan transformasional dan pelatihan sumber daya manusia dengan employee well-being yang tidak dapat dimediasi oleh keadilan organisasional (no mediation).

Implikasi dari penelitian ini terhadap perusahaan secara umum adalah agar perusahaan dapat lebih memperhatikan para pekerjanya, sehingga nantinya mampu untuk mempertahankan dan meningkatkan employee well-being dalam perusahaan yang bersangkutan. Dalam penelitian ini juga terdapat keterbatasan studi seperti kecilnya ukuran sampel yang digunakan, sehingga akan disarankan kepada peneliti selanjutnya untuk lebih memperbesar ukuran sampel yang nantinya akan digunakan. Selain itu, peneliti selanjutnya juga disarankan untuk menggunakan variabel mediasi yang lain yang lebih berkaitan dengan variabel dependen dan independen berdasarkan data-data yang lebih terperinci. Namun, peneliti selanjutnya juga bisa membahas hubungan antara variabel independen dengan dependen secara langsung, dengan pembahasan yang lebih detail dan mandalam. Saran bagi perusahaan, diharapkan dapat mempertahankan dan meningkatkan kepemimpinan transformasional serta melakukan pelatihan sumber daya manusia secara berkala dan dengan prosedur yang baik guna meningkatkan employee wellbeing dalam suatu perusahaan. Dengan demikian, salah satu modal perusahaan yang paling utama adalah tenaga kerja atau sumber saya manusia (human capital).

\section{REFERENSI}

Afsar, B., \& Umrani, W. A. (2019). Transformational leadership and innovative work behavior: The role of motivation to learn, task complexity, and innovation climate. Industrial Management \& Data Systems, 114(8), 1270-1300. https://doi.org/10.1108/IMDS-05-2014-0152

Amanda, R., \& Sadida, N. (2018). Hubungan antara health consciousness dengan employee well-being pada karyawan di DKI Jakarta. Journal of Psychological Science and Profession, 2(3), 216-221. https://doi.org/10.24198/jpsp.v2i3.19223 
Arnold, K. A. (2017). Transformational leadership and employee psychological wellbeing: A review and directions for future research. Journal of Occupational Health Psychology, 22(3), 381-393. https://doi.org/10.1037/ocp0000062

Casademunt, A. M. L., Molina, D. C., \& Cabrera, A. M. G. (2018). The role of human resource practices and managers in the development of well-being: Cultural differences in the changing workplace. Cross Cultural \& Strategic Management, 25(2), 716-740. https://doi.org/10.1108/CCSM-052017-0054

Fernandes, A. A. R., \& Fresly, J. (2017). Modeling of role of public leader, open government information, and public service performance in Indonesia. Journal of Management Development, 36(9), 1160-1169. https://doi.org/10.1108/JMD-12-2016-0322

Gope, S., Elia, G., \& Passiante, G. (2018). The effect of HRM practices on knowledge management capacity: A comparative study in Indian IT industry. Journal of Knowledge Management, 22(3), 649-677. https://doi.org/10.1108/JKM-10-2017-0453

Hair, J. F., Sarstedt, M., Hopkins, L., \& Kuppelwieser, V. G. (2014). Partial least squares structural equation modeling (PLS-SEM): An emerging tool in business research. European Business Review, 26(2), 106-121. https://doi.org/10.1108/EBR-10-2013-0128

Hidayat, D. P. (2015). Pengaruh keadilan organisasional terhadap komitmen afektif melalui kepuasan kerja pada perusahaan perbankan swasta di DKI Jakarta. Jurnal Manajemen dan Pemasaran Jasa, 8(1), 1-26. https://doi.org/10.25105/jmpj.v8i2.1589

Inceoglu, I., Thomas, G., Chu, C., Plans, D., \& Gerbasi, A. (2018). Leadership behavior and employee well-being: An integrated review and a future research agenda. The Leadership Quarterly, 29(1), 179-202. https://doi.org/10.1016/j.leaqua.2017.12.006

Jaiswal, A., \& Dyaram, L. (2019). Towards well-being: Role of diversity and nature of work. Employee Relations, 41(1), 158-175. https://doi.org/10.1108/ER-11-2017-0279

Josef, E. S. (2017). Pengaruh dimensi keadilan organisasional terhadap perilaku kerja kontraproduktif karyawan. Jurnal Ilmu Manajemen, $\quad 5(1), \quad$ 1-9. https://jurnalmahasiswa.unesa.ac.id/index.php/jim/article/view/18394

Jufrizen \& Lubis, A. S. P. (2020). Pengaruh kepemimpinan transformasional dan kepemimpinan transaksional terhadap kinerja pegawai dengan locus of control sebagai variabel moderating. Jurnal Ilmiah Magister Manajemen, 3(1), 41-59. https://doi.org/10.30596/maneggio.v3i1.4874

Khaola, P., \& Rambe, P. (2020). The effects of transformational leadership on organisational citizenship behaviour: The role of organisational justice and affective commitment. Management Research Review, 44(3), 381-398. https://doi.org/10.1108/MRR-07-2019-0323

Khoreva, V., \& Wechtler, H. (2018). HR practices and employee performance: The mediating role of well-being. Employee Relations, 40(2), 227-243. https://doi.org/10.1108/ER-08-2017-0191

Kim, S., Tam, L., Kim, J. N., \& Rhee, Y. (2017). Determinants of employee turnover intention: Understanding the roles of organizational justice, supervisory justice, authoritarian organizational culture, and organization-employee relationship quality. Corporate Communications: An International Journal, 22(3), 308-328. https://doi.org/10.1108/CCIJ-11-2016-00744

Kuncoro, M. (2013). Metode riset untuk bisnis \& ekonomi: Bagaimana meneliti dan menulis tesis?. Erlangga.

Le, H., Zheng, C., \& Fujimoto, Y. (2016). Inclusion, organisational justice, and employee well-being. International Journal of Manpower, 37(6), 945-964. https://doi.org/10.1108/IJM-12-2015-0212

Nielsen, R., \& Marrone, J. A. (2018). Humility: Our current understanding of the construct and its role in organizations. International Journal of Management Reviews, 20(4), 805-824. https://doi.org/10.1111/ijmr.12160

Otalora, M. L., Garcia, N. P., \& Sanchez, I. D. (2020). Interpersonal conflict at work and knowledge hiding in service organizations: The mediator role of employee well-being. International Journal of Quality and Service Sciences, 13(1), 63-90. https://doi.org/10.1108/IJQSS-02-2020-0023

Rizky, T. R., \& Sadida, N. (2019). Hubungan antara job insecurity dan employee well-being pada karyawan yang bekerja di perusahaan yang menerapkan PHK di DKI Jakarta. Jurnal Empati, 8(1), 329-335. https://ejournal3.undip.ac.id/index.php/empati/article/view/23651

Samad, A., Muchiri, M., \& Shahid, S. (2021). Investigating leadership and employee well-being in higher education. Personnel Review. https://doi.org/10.1108/PR-05-2020-0340 
Septyan, F. B., Musadieq, M. A., \& Mukzam, M. D. (2017). Pengaruh kepemimpinan transformasional terhadap motivasi dan kinerja. Jurnal Administrasi Bisnis, 53(1), 81-88. http://administrasibisnis.studentjournal.ub.ac.id/index.php/jab/article/viewFile/2185/2583

Septyarini, E., \& Pratiwi, R. N. (2020). Pengaruh keadilan organisasional dan profesionalisme kepemimpinan terhadap kesejahteraan psikologis karyawan. Maker: Jurnal Manajemen, 6(2), 157-168. https://doi.org/10.37403/mjm.v6i2.197

Sharma, P., Kong, T. T. C., \& Kingshott, R. P. J. (2016). Internal service quality as a driver of employee satisfaction, commitment, and performance: Exploring the focal role of employee well-being. Journal of Service Management, 27(5), 773-797. https://doi.org/10.1108/JOSM-10-2015-0294

Terzi, A. R., Dülker, A. P., Altın, F., Çelik, F., Dalkiran, M., Yulcu, N. T., Tekin, S., \& Deniz, Ü. (2017). An analysis of organizational justice and organizational identification relation based on teachers' perceptions. Universal Journal of Educational Research, 5(3), 488-495. https://doi.org/10.13189/ujer.2017.050320

Zhang, I., Lin, Z., Liu, Y., Chen, X., \& Liu, D. M. (2020). How do human resource management practices affect employee well-being? A mediated moderation model. Employee Relations, 42(4), 903-919. https://doi.org/10.1108/ER-08-2019-0320

Zheng, X., Zhu, W., Zhao, H., \& Zhang, C. (2015). Employee well-being in organizations: Theoretical model, scale development, and cross-cultural validation. Journal of Organizational Behavior, 36(5), 645-647. https://doi.org/10.1002/job.1990

Zhong, J., Zhang, L., Li, P., \& Zhang, D. Z. (2019). Can leader humility enhance employee wellbeing? The mediating role of employee humility. Leadership \& Organization Development Journal, 41(1), 19-36. https://doi.org/10.1108/LODJ-03-2019-0124 
Jurnal Manajemen Maranatha — Vol. 21 Nomor 1, November (2021) 